\title{
Design of Information Systems for Food Distribution Control in LDPM Batutaba Sepakat
}

\section{Perancangan Sistem Informasi Untuk Pengendalian Distribusi Pangan pada LDPM Batutaba Sepakat}

\author{
Novia Lestari \\ Manajemen Informatika, Universitas Mahaputra Muhammad Yamin, Sumatera Barat, Idnonesia \\ Email: novia_lestarii@rocketmail.com
}

\begin{abstract}
This study aims to assist LDPM (Community Food Distribution Institute) in facilitating the recording of transactions and distribution of grain from and to farmers so that it can provide information that can speed up the work process at LDPM Batutaba Agreed in serving farmers who sell grain at LDPM Batu Taba Sepakat. This information system itself was built using Object Oriented Programming Language, Delphi 7. With the SDLC system development model consisting of 7 (seven) steps, namely identification and selection, initiation and planning, analysis, logical design, physical design, implementation, and maintenance expected can create an information system that is in accordance with the needs of the LDPM Batu Taba Sepakat, so that there is an increase in food sales and distribution transaction data management that can improve the welfare of the people of Batu Taba, especially farmers.
\end{abstract}

Keywords: Information system, food distribution

\section{PENDAHULUAN}

Kecamatan Ampek Angkek merupakan sakah satu sentra produksi padi di Kabupaten Agam, bahkan memiliki predikat selaku penghasil padi/beras unggul yang dikenal dengan "Beras Ampek Angkek". Namun dengan predikat yang disandang oleh daerah Ampek Angkek, khususnya daerah Batu Taba, masyarakat petani belum dapat secara maksimal menikmati hasil yang diperoleh pada saat musim panen padi. Hal ini disebabkan karena besarnya fluktuasi harga gabah petani. Pada saat panen raya petani harus menjual gabahnya dengan harga yang rendah, dan pada saat paceklik petani harus membeli gabah/beras dengan harga yang sangat tinggi.

Mengingat petani selalu berada dalam posisi yang kurang menguntungkan disaat menghadapi panen maupun menghadapi paceklik, pemerintah memfasilitasi dan mendorong petani untuk tidak berjalan sendiri-sendiri tetapi dapat membangun kebersamaan dalam bentuk kumpulan petani dalam satu kelompok tani (Poktan) 
atau bergabung dalam bentuk gabungan kelompok tani (Gapoktan). Maka sejak tahun 2009 yang bersumber dari dana Dekonsentrasi APBN dari Badan Ketahanan Pangan Kementrian Pertaniaan dibentuklah kegiatan penguatan LDPM (Lembaga Distribusi Pangan Masyarakat), dimana disalurkan dana Bantuan Sosial (Bansos) langsung ke Gapoktan, kegiatan pembelian dan penjualan gabah/beras serta membangun sarana penyimpanan beras/gabah. Program penguatan LDPM merupakan program Kementerian Pertanian melalui badan ketahanan pangan, yang bertujuan untuk menjaga ketahanan pangan wilayah melalui pengembangan unit usaha distribusi pangan dan unit pengelola cadangan pangan. Program penguatan LDPM adalah program pemberdayaan melalui pemberian dana bantuan sosial untuk meningkatkan usaha ekonomi di wilayah melalui peningkatan usaha pembelian dan penjualan serta pengembangan unit pengelola cadangan pangan yang ada pada gaoktan. Rancangan program penguatan LDPM melalui beberapa tahap yaitu tahap penumbuhan, pengembangan, kemandirian dan pasca kemandirian [1]. Namun anggaran ini baru resmi dilaksanakan pada tahun 2014, dan LDPM Batu Taba sendiri baru memulai kegiatan ini pada tahun 2016.

Sebagai instansi yang baru mulai berjalan, LDPM Batu Taba masih menggunakan sistem semikomputerisasi dalam menjalankan administrasinya, mulai dari pencatatan panjualan Gabah Kering Giling $(\mathrm{GKG})$ dan Gabah Kering Panen(GKP), pembelian GKG dan GKP, bukti penjualan GKG dan GKP yang belum ada, serta jumlah stok GKG dan GKP yang tersedia di setiap bulannya yang belum jelas pencatatannya. Sehingga kegiatan pencatatan atau pengumpulan data barang masuk yang bersumber dari dokumen permintaan GKP dan GKG, rekapitulasi data barang maupun hutang, penciptaan informasi atau laporanlaporan tekait dengan distribusi GKP dan GKG, sampai proses pendistribusian informasi tersebut kepada pimpinan belum optimal, sering terjadi kesalahan pencatatan data, adanya data ganda, dan kehilangan data.

Berdasarkan hal tersebut di atas, perlu dikembangkan sebuah sistem informasi yang sesuai dengan kebutuhan LDPM Batu Taba dalam pengelolaan data transaksi penjualan dan distribusi pangan yang dapat mempermudah dalam pencatatan proses transaksi penjualan dan distribusi Gabah Kering Giling (GKG) maupun Gabah Kering Panen(GKP). Selain itu, dengan adanya database elektonik yang dibangun, dapat membantu meminimalkan terjadinya kehilangan maupun kerangkapan data sehingga bisa menghasilkan laporan-laporan yang dibutuhkan secara cepat dan tepat yang dapat menunjang kinerja LDPM Batu Taba dalam melayani petani di daerah tersebut.

Sistem informasi merupakan sebuah sistem di dalam suatu organisasi yang mempertemukan berbagai kebutuhan proses pengolahan transaksi harian, membantu dan mendukung seluruh kegiatan operasi yang bersifat manajerial 
daari suatu organisasi dan membantu memperlancar penyediaan laporan yang dibutuhkan [2]. Berdasarkan penelitian terdahulu, sistem informasi memiliki peran yang sangat penting dalam meningkatkan pencatatan transaksi, proses penyimpanan data menjadi lebih baik dikarenakan setiap penyimpanan data tersimpan dalam database sehingga terjadinya kehilangan data dan duplikasi data dapat diminimalkan serta proses pencarian data menjadi lebih cepat [3]. Selain itu, Pencatatan data secara manual dapat mempengaruhi munculnya kesalahan, oleh karena itu dibutuhkan perancangan suatu sistem informasi, sehingga waktu yang dibutuhkan untuk mencari data tidak panjang dan aliran informasi menjadi lebih sederhana [4]. Dengan adanya sistem informasi dapat mempermudah dalam penyajian informasi serta data yang disajikan dapat menunjang kegiatan operasional [5].

\section{METODOLOGI PENELITIAN}

Metodologi yang digunakan untuk mengembangkan sistem dalam penelitian ini sebagaimana yang biasa digunakan para peneliti di bidang komputer yaitu System Development Life Cycle (SDLC) atau siklus hidup pengembangan sistem. Berikut ini penjabaran kegiatan selama dilakukan penelitian sesuai tahapan SDLC :

1. Identification and Selection, Fase ini adalah awal dari kegiatan penelitian dimana dilakukan peninjauan langsung kelokasi penelitian yaitu pada LDPM Batu Taba Sepakat. Adapun kegiatan pada fase ini adalah mengamati pelaksanaan kegiatan Sistem Informasi (SI) pada Distribusi Pangan tersebut, mulai dari proses pencatatan atau pengumpulan data, rekapitulasi data, penciptaan informasi, sampai kepada pendistribusian informasi atau laporanlaporan untuk pihak yang membutuhkan.

2. Initiation and Planning, kegiatan awal (inititation) adalah dengan mulai menganalisa bentuk-bentuk laporan yang diperlukan, jenis data yang harus dikumpulkan, personal yang terlibat pada kegiatan SI, dan prosedur kerja yang digunakan. Berdasarkan hasil analisa yang lebih terperinci tersebut, maka disusun rencana (planning) untuk meningkatkan penerapan komputer secara lebih optimal didalam menunjang kegiatan SI Distribusi Pangan pada LDPM Batu Taba Sepakat.

3. Analysis, Pada fase ini dibuat model perancangan sistem menggunakan alat model grafis dengan Unified Modeling Language (UML) seperti Use Case Diagram, Activity Diagram, Object Diagram, Class Diagram, Sequence Diagram, dan Component Diagram. Model grafis yang dihasilkan untuk selanjutnya menjadi pedoman didalam merancang SI baru berbasis komputer secara lebih optimal.

4. Logical Design, Pada fase ini dilakukan penyusunan logika yang mendasari unjuk kerja program aplikasi yang dibangun yaitu dengan menjabarkan Flowchart dan UML maupun organisasi database yang diperlukan.

5. Physical Design, Fase ini merupakan kelanjutan dari fase ke-4 yaitu dengan mengkonversi / menterjemahkan rancangan logika yang telah terbentuk 
kedalam bahasa pemrograman yang ditetapkan atau disebut juga dengan proses Coding.

6. Implementation, Pada fase ini dilakukan penerapan terhadap modul program aplikasi yang telah dibangun, yaitu mulai dari meng-install sistem operasi windows yang telah sesuai, program aplikasi untuk SI Distribusi Pangan yang menggunakan bahasa pemograman Delphi 7. Selain itu, pada fase ini juga dilakukan pelatihan kepada para pengguna program aplikasi yang dibangun.

7. Maintenance, Pada fase ini dilakukan pemeliharaan sistem yaitu kegiatan kemungkinan melakukan pemutakhiran (update) data, mengganti sistem database, maupun mengkonversi kebahasa pemrograman terbaru suatu saat nanti.

\section{HASIL DAN PEMBAHASAN}

Setelah dilakukan analisis terhadap kegiatan yang berjalan selama ini di LDPM Batu Taba Sepakat dapat digambarkan analisis SWOT berikut :

\section{a. Kekuatan (strengt)}

Pada kegiatan distribusi pangan, LDPM telah menggunakan interface berupa faktur dan kwitansi untuk memudahkan bagian distribusi menginputkan data barang pada waktu input data keuangan sehingga lebih akurat.

\section{b. Kelemahan (weakness)}

Dari pantauan peneliti, sekarang ini proses kerja ditribusi pangan masih kurang efektif sekalipun telah menggunakan faktur dan kwitansi untuk diinputkan ke buku PP, namun pengisisan yang masih dilakukan secara manual dengan cara tulisan tangan sehingga memungkinkan terjadi kesalahan penulisan, ketidakakuratan data, kerusakan atau kehilangan data.

c. Peluang (oppoturnity)

Dengan mengunakan sistem informasi yang lebih baik, maka diharapkan distribusi pangan pada LDPM Batu Taba Sepakat dapat semakin baik. Sehingga LDPM Batu Taba Sepakat dapat melayani petani dengan lebih baik dalam hal pencatatan transaksi dan distribusi gabah dan bisa bersaingan dengan LDPM yang lainnya di Indonesia.

\section{d. Ancaman (threat)}

Kurangnya keahlian pihak pemakai terhadap aplikasi yang dibuat akan mengancam bertahannya pemakaian aplikasi tersebut.

Dari hasil analisis SWOT tersebut di atas terkait dengan sistem transaksi dan distribusi pangan yang ada, maka selanjutnya dirancang sistem informasi baru yang bertujuan untuk meningkatkan kekuatan (strenght) dan peluang (opportunity) dari kegiatan yang ada sekaligus mengurangi kelemahan (weakneses) dan ancaman (tbreath) yang ada. Berikut ini adalah uraian dari model rancangan SI baru menggunakan model grafis UML. 
Vol. 1, No. 2, September 2019

p-ISSN: 2656-5935 http://journal-isi.org/index.php/isi e-ISSN: 2656-4882

\section{a. Use Case Diagram SI Baru}

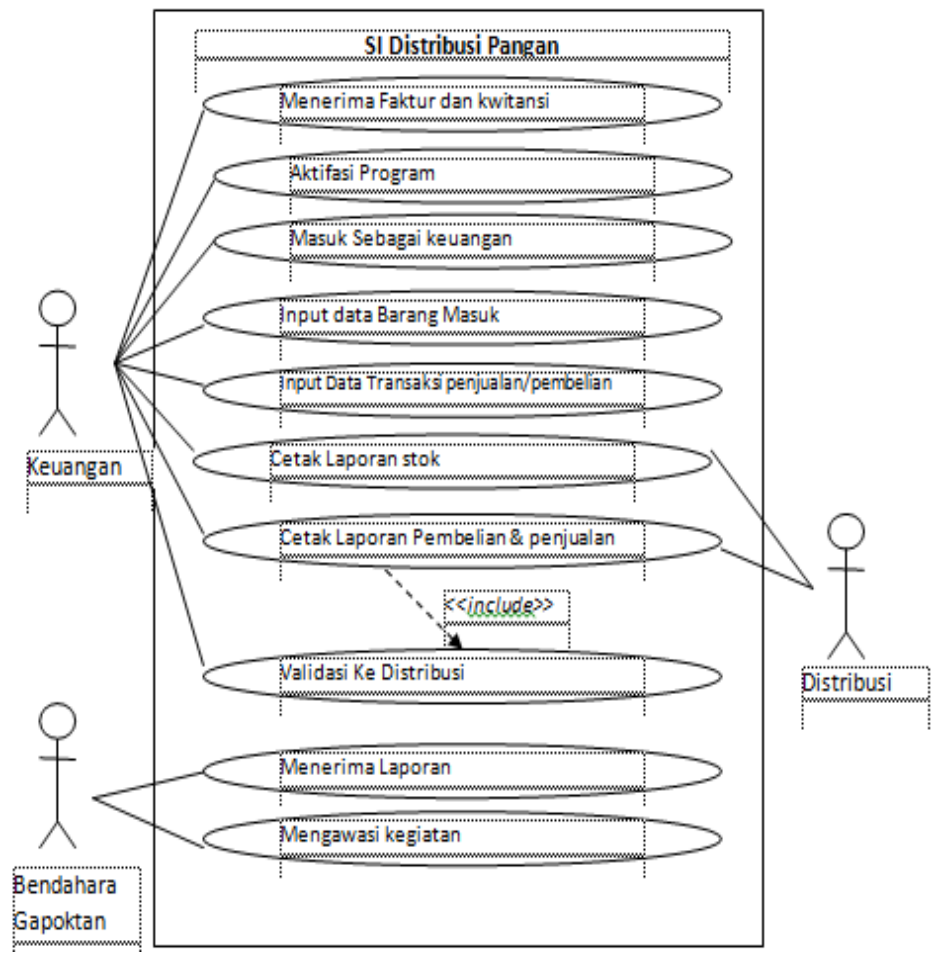

\section{Gambar 1. Diagram USE CASE dari SI baru}

Gambar 1 di atas menggambarkan interaksi 2 (dua) environment sistem atau disebut juga aktor utama yaitu (1) keuangan dan bendahara gapoktan serta 1 (actor pendukung). Aktor utama yang pertama yaitu keuangan melaksanakan 8 (delapan) kegiatan dengan 8 (delapan) USE CASE yaitu (1) menerima faktur dan kwitansi, (2) mengaktifkan proram aplikasi, (3)login sebagai user (4) menginputkan data barang masuk, (5) menginputkan data transaksi penjualan maupun pembelian, (6) cetak laporan stok (7) Cetak laporan penjualan maupun pembelian pangan yang di sertakan oleh validasi dari Distribusi. (8) menyerahkan laporan ke pada distribusi.

\section{b. Activity Diagram}

Activity diagram merupakan alat pemodelan grafis yang dapat digunakan untuk menggambarkan kegiatan yang dilakukan actor terhadap sistem, maupun sistem itu sendiri, dan juga menggambarkan cara kerja modul program aplikasi yang dirancang. Seperti yang terlihat pada Gambar 2 berikut: 
Vol. 1, No. 2, September 2019

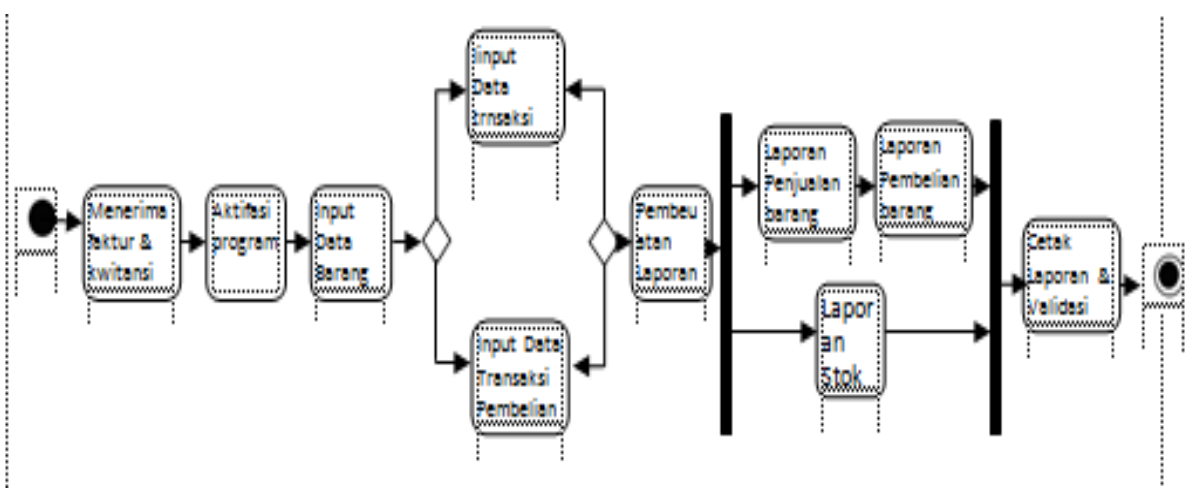

Gambar 2. Activity Diagram

\section{c. Class Diagram}

Rancangan class diagram didasarkan pada obyek-obyek yang ditemukan di lingkungan pada LDPM. Setiap Class yang dihasilkan dalam rancangan adalah merupakan cikal bakal dari sebuah tabel atau file data yang diciptakan untuk menunjang program aplikasi yang dibangun. Gambar 3 berikut ini adalah Class Diagram sebagai dasar pembentukan file atau tabel-tabel data pendukung modul program aplikasi komputer yang dirancang untuk meningkatkan kegiatan sistem distribusi pangan pada LDPM Batutaba.

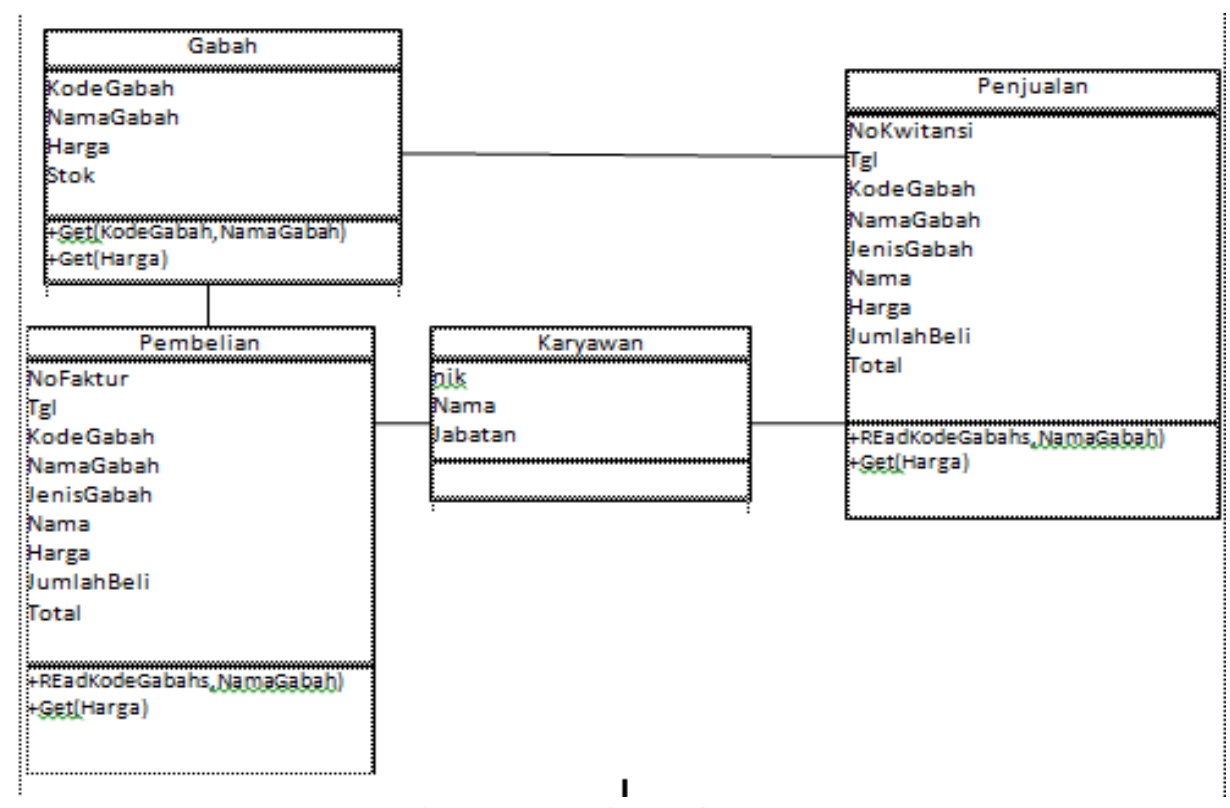

Gambar 3. Class Diagram 
Vol. 1, No. 2, September 2019

p-ISSN: 2656-5935 http://journal-isi.org/index.php/isi

e-ISSN: 2656-4882

\section{d. Sequence Diagram}

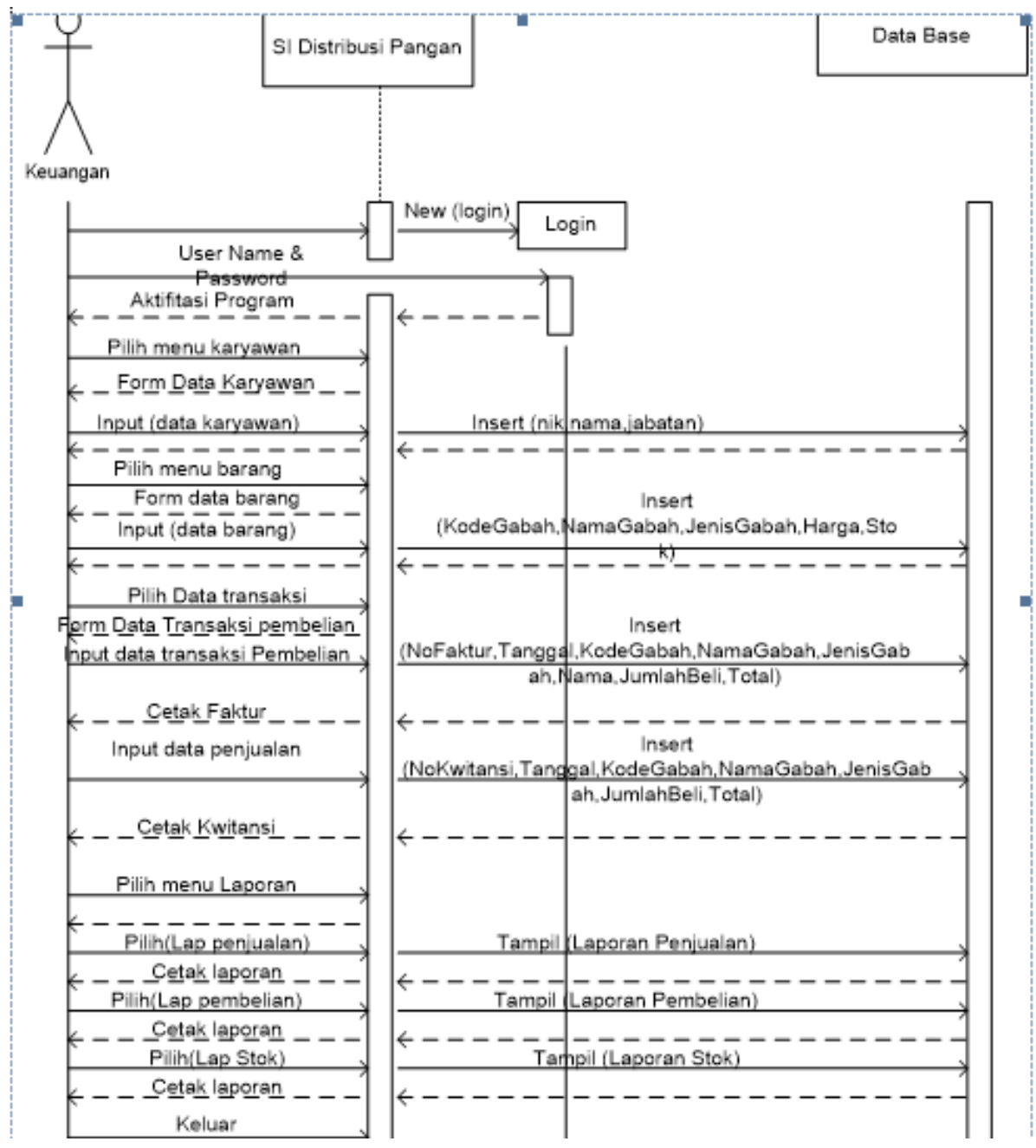

Gambar 4. Sequence Diagram

\section{Tampilan Antar Muka Sistem Informasi}

\section{Menu Utama}

Menu Utama berisi pilihan-pilihan submenu yang akan dijalankan pada Sistem Informasi Pengendalian Distribusi Pangan, yang terdiri dari : data karyawan, data barang, pembelian, penjualan, dan laporan. Halaman menu utama dibuat user friendly, sehingga operator yang menggunakan sistem lebih mudah dalam mengoperasikan sistem informasi tersebut.

Halaman menu utama dapat dilihat pada Gambar 5 berikut ini : 
Vol. 1, No. 2, September 2019

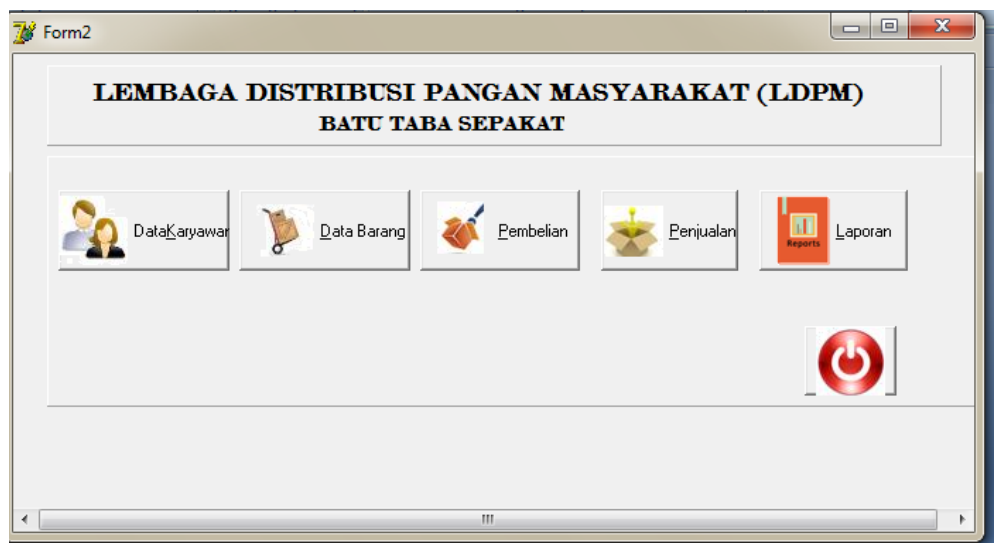

Gambar 5. Tampilan Menu Utama

\section{Form Data Karyawan}

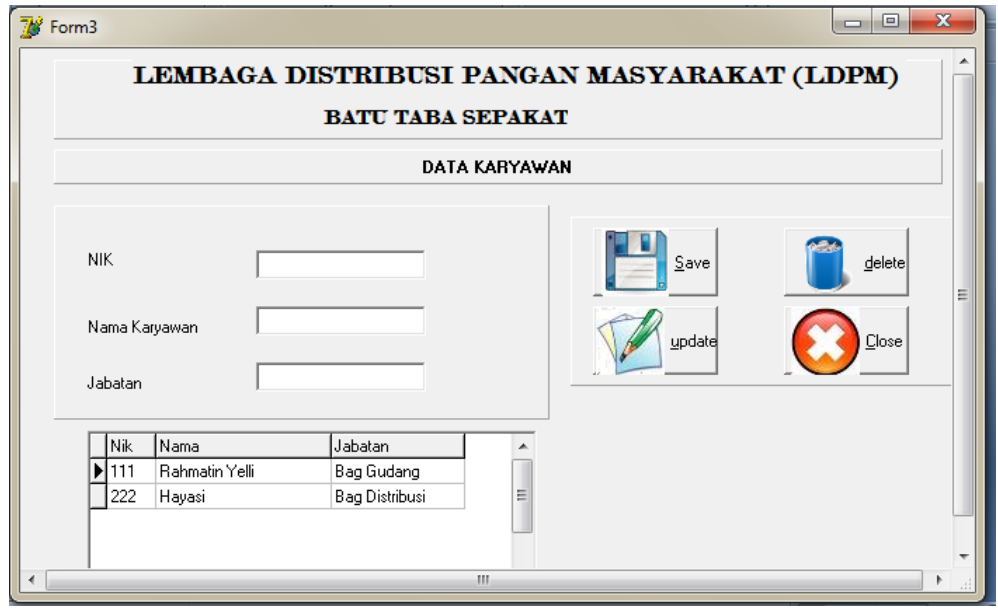

Gambar 6. Tampilan Form Data Karyawan

Form data karyawan seperti terlihat pada Gambar 6 di atas berfungsi untuk menginputkan data karyawan Lembaga Distribusi Pangan Masyarakat (LDPM) Batu Taba Sepakat.

\section{Form Data Barang/Gabah}

Form data barang seperti terlihat pada Gambar 7 berikut berfungsi untuk menginputkan data gabah yang akan dibeli dan dijual dari dan ke petani.Mulai dari Kode gabah, nama gabah, jenis gabah (Gabah Kering Giling (GKG) maupun Gabah Kering Panen(GKP)), harga gabah, serta stok gabah, sehingga pencatatan data gabah lebih jelas dan tersimpan dengan baik dalam 
Vol. 1, No. 2, September 2019

p-ISSN: 2656-5935

database elektronik yang jika sewaktu-waktu diperlukan dapat dengan mudah diakses kembali.

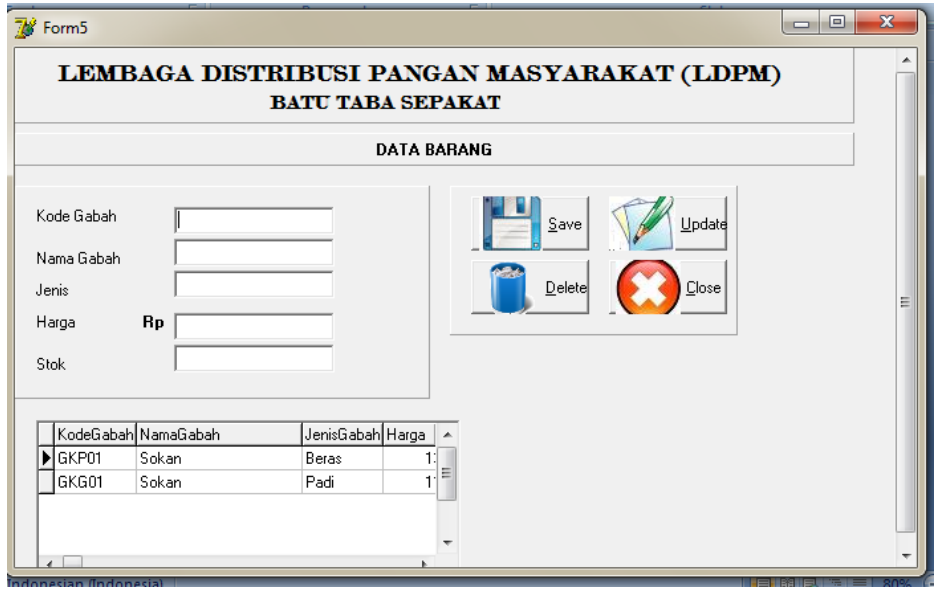

\section{Gambar 7. Tampilan Form Data Barang/Gabah}

\section{Form Transaksi Pembelian Gabah}

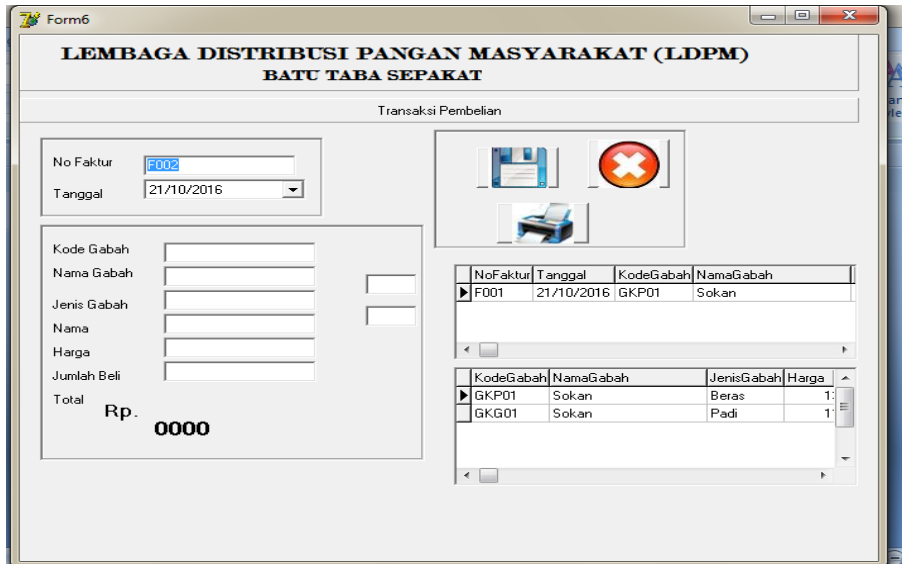

Gambar 8. Tampilan Form Transaksi Pembelian

Form transaksi pembelian seperti terlihat pada Gambar 8 di atas berfungsi untuk menginputkan transaksi pembelian gabah dari petani sesuai dengan nama dan jenis gabah. Dari form transaksi pembelian gabag ini dikeluarkan bukti transaksi dalam bentuk faktur, sehingga nantinya mempermudah dalam perekapan data transaksi dan pelaporan kepada pimpinan LDPM Batu Taba Sepakat. 


\section{KESIMPULAN}

Dengan adanya Sistem Informasi untuk pengendalian distribusi pangan ini, akan memudahkan pihak LDPM dalam peningkatan pengelolaan data transaksi penjualan dan mengefesienkan pencatatan distribusi pangan/Gabah. Sehingga kegiatan pencatatan atau pengumpulan data barang masuk yang bersumber dari dokumen permintaan GKP dan GKG, rekapitulasi data barang maupun hutang lebih jelas dan terstruktur tanpa adanya kesalahan pencatatan, data ganda, apalagi kehilangan data.

Ditunjang dengan keberadaan database elektronik yang ada, akan lebih meminimalkan terjadinya kehilangan maupun duplikasi data sehingga bisa menghasilkan laporan-laporan secara tepat dan cepat, penciptaan informasi atau laporan-laporan tekait dengan distribusi GKP dan GKG, sampai proses pendistribusian informasi tersebut kepada pimpinan menjadi lebih optimal. Sehingga program pemberdayaan masyarakat terutama dalam distribusi pangan mencapai tujuan yang diinginkan yaitu dapat meningkatkan kesejahteraan masyarakat Batu Taba khususnya petani.

\section{DAFTAR PUSTAKA}

[1] Undang-Undang Negara Republik Indonesia No. 19 Tahun 2013. "Tentang Perlindungan dan Pemberdayaan Petani".

[2] Hamdani, A. U., \& Fk, M. A. (2015). "Pemodelan Sistem Informasi Administrasi Pendistribusian Kartu Asuransi Akda Extra Studi Kasus : PT. Asuransi Bhakti Bhayangkara Jakarta", Seminar Nasional Teknologi Informasi dan Komunikasi (Sentika).

[3] Prabowo, F. A., Syani, M., Jauh, J., \& Di, P. (2017). "Sistem Informasi Pengolahan Sertifikat Berbasis Web Di Divisi Training Seamolec", Jurnal Masyarakat Informatika Indonesia (JMII) Vol 1/IV/2016) JMII Vol 2, No. 1, Januari-Maret 2017 ISSN: 2541-5093,73-81.

[4] Rahmayanti, D., \& Afrinando, R. (2013). "Perancangan Sistem Informasi Pada Bagian Gudang PT.PN VI Unit Usaha Ophir". Jurnal Optimasi Sistem Industri, vol.12 No.2, Oktober 2013, pp 420-426/ISSN 2088-4842

[5] Pranata, Galih dkk.. (2014). "Rancang Bangun Sistem Informasi Permintaan Pembelian Barang Berbasis Web di STMIK STIKOM Surabaya", Jurnal Sistem Informasi, JSIKA Vol 3 No.1, ISSN: 2338-137X. 